\title{
Особливості перебігу анемічного синдрому у хворих на цүкровий діабет
}

\section{А.М. Урбанович, Ю.В. Дунець}

Львівський національний медичний університет імені Данила Галицького

\begin{abstract}
Резюме. У цьому огляді висвітлено особливості перебігу анемій різної етіології у хворих на цукровий діабет (ЦД). ЦД - одне з найпоширеніших хронічних захворювань, яке поступово набуває рис неінфекційної епідемії та є однією з найгостріших медико-соціальних проблем сучасності, що охоплює більшість економічно розвинених держав. Оскільки ЦД вражає усі органи та системи організму, анемічний синдром може мати мультифакторний генез. Зниження рівня гемоглобіну (Hb) погіршує контроль вуглеводного обміну, сприяє швидкому розвитку діабетичної ретинопатії та нейропатії. Хворі на ЦД знаходяться в зоні ризику щодо розвитку залізодефіцитної анемії та анемії, пов'язаної з дефіцитом еритропоетину через розвиток хронічної хвороби нирок. Залізодефіцитна анемія $є$ найпоширенішою серед усіх хворих, зокрема й у хворих на ЦД. Гуморальним регулятором рівня заліза в організмі є гепсидин, який являє собою амінокислотний пептид, багатий на цистеїн, із дисульфідними місточками, і синтезується в печінці. Відомо, що при гіпоксії зменшується експресія гену гепсидину та збільшується засвоєння заліза як із макрофагів, так і з кишківника, відповідно гепсидин $є$ основним регуляторним пептидом, що забезпечує гомеостаз заліза в організмі. Із розвитком діабетичної хронічної хвороби нирок ймовірність розвитку анемії різко зростає, оскільки виникає дефіцит еритропоетину. Також постійне приймання метформіну, який є препаратом першої лінії для лікування ЦД 2-го типу, підвищує ймовір-

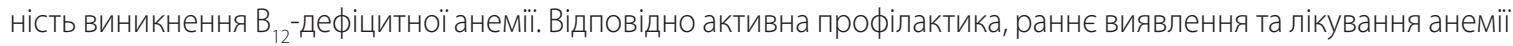
у хворих на ЦД дозволить сповільнити розвиток хронічних ускладнень та покращити якість життя пацієнтів.
\end{abstract}

Ключові слова: анемія, цукровий діабет, хронічна хвороба нирок, гепсидин, метформін.

Анемія належить до одних із найпоширеніших захворювань у світі. За даними ВООЗ близько 1,62 млрд світового населення страждають від цієї хвороби, що становить 24,8\% світової популяції [1]. Відомо, що наявність анемії підвищує рівень смертності, має негативний психосоціальний вплив та порушує неврологічний розвиток у дітей [2].

Анемія являє собою сукупність клінічних та гематологічних синдромів, які характеризуються зниженням рівня Нb нижче 120 г/л для жінок та 130 г/л для чоловіків і/ або зниженням рівня еритроцитів $3,8 \times 10^{12}$ г/л для жінок та 4,0×1012 г/л для чоловіків [3, 4].

Існують різні класифікації анемій, зокрема і за причиною виникнення [1]:

- анемія внаслідок зменшеного утворення еритроцитів (залізодефіцитна анемія, $\mathrm{B}_{12}{ }^{-}$ фолієводефіцитна анемія, мегалобластні та апластині анеміi); 
Огляди

- анемія внаслідок підвищеної втрати еритроцитів (гостра або хронічна крововтрата);

- анемія внаслідок підвищеного руйнування еритроцитів (анемії, спричинені вірусними та бактеріальними інфекціями, гемоглобінопатії, гемолітичні анеміï).

Крім того, існує класифікація анемій за ступенем важкості [1]:

- легкий - рівень Нb 95-109 г/л;

- середній - рівень Нb 80-94 г/л;

- тяжкий - рівень Нb 65-79 г/л;

- дуже тяжкий - рівень $\mathrm{Hb}<65$ г/л.

Основними симптомами при анемії будьякого генезу є загальна слабкість, підвищена втомлюваність, порушення здатності до концентрації та уваги, біль голови й запаморочення, тахікардія і задишка (при тяжкій формі), блідість шкіри й слизових оболонок.

Доведено, що при захворюваннях ендокринної системи в пацієнтів часто виникає анемічний синдром. Зокрема, анемія може бути одним із перших симптомів при гіпотиреозі [5] та часто супроводжує і ускладнює перебіг ЦД [6].

ЦД - одне $з$ найпоширеніших хронічних захворювань, яке поступово набуває рис неінфекційної епідемії і є однією 3 найгостріших медико-соціальних проблем сучасності, що охоплює більшість економічно розвинених держав. У зв'язку з ранньою інвалідизацією та високою смертністю від пізніх ускладнень ЦД, він належить до числа серйозних медико-соціальних і економічних проблем. Ризик розвитку у хворих на ЦД ішемічної хвороби серця та інфаркту міокарда збільшується у 2-5 разів, патології нирок - у 17-20 разів, інсульту у 2-3 рази; повної втрати зору в 10-25 разів; гангрени нижніх кінцівок - у 20 разів [7]. Biдомо, що ЦД скорочує тривалість життя на 2-12\% внаслідок різноманітних ускладнень. Найважчі серед них пов'язані з порушенням кровопостачання органів і тканин через залучення в процес як магістральних, так і дрібних периферичних артерій.

Оскільки ЦД вражає більшість органів і систем в організмі людини, анемія є частим ускладненням даного захворювання. Зокрема, у хворих на ЦД захворюваність на анемію зустрічається у 2-3 рази частіше, ніж у здорової популяції [8]. Відомо, що у хворих на Цд анемія виникає раніше та має важчий перебіг ніж, наприклад, у хворих з ураженням нирок іншою патологією. Згідно з науковими джерелами, низький рівень Нb прискорює розвиток макро- та мікроангіопатій при Цд [9].

Як було згадано вище, існують різні етіологічні чинники виникнення анемії. Залізодефіцитна анемія є найпоширенішою серед усіх хворих, зокрема й у хворих на ЦД. Залізодефіцитна анемія являє собою клініко-гематологічний синдром, обумовлений дефіцитом заліза в організмі, який приводить до порушення синтезу Нb. Основні симптоми при залізодефіцитній анемії обумовлені розвитком гематологічного, гіпоксичного та сидеропенічного синдромів.

Гематологічний синдром характеризується розвитком гіпохромної анемії, мікроцитозом, пойкілоцитозом та анізоцитозом еритроцитів. Гіпоксичний синдром обумовлений розвитком дефіциту $\mathrm{Hb}$ i, як наслідок, зниженням надходження кисню до всіх тканин організму, що проявляється загальною слабкістю, втомлюваністю, запаморокою, шумом у вухах, серцебиттям, задишкою, блідістю шкіри. Сидеропенічний синдром обумовлений дефіцитом заліза та проявляється наступними симптомами: спотворення смаку (pica chlorotica), виражена м'язова слабкість, дистрофічні зміни шкіри (сухість шкіри, ламкість, випадіння волосся, тьмяність і ламкість нігтів; койлоніхії - ложкоподібні ввігнуті нігті), ангулярний стоматит і сидеропенічна дисфагія.

В організмі людини існують різні системи, які активуються при дефіциті заліза або при його надлишку. У випадку зниження рівня заліза в організмі збільшується його абсорбція ентероцитами за допомогою системи регуляторів насичення, після чого воно поступає в плазму крові, зв'язується з трансферином та трансформується у феритин. Своєю чергою, транспортування заліза в тканини здійснюють білок спадкового гемохроматозу і ферропортин [10].

Гуморальним регулятором рівня заліза в організмі є гепсидин, який являє собою амінокислотний пептид, багатий на цистеїн, із дисульфідними місточками, і синтезується в печінці. Відомо, що при гіпоксії зменшується експресія гену гепсидину та збільшується засвоєння заліза як із макрофагів, так і з кишківника [1113]. Водночас відбувається збільшення рівня 
еритропоетину та еритропоетичної активності, що зумовлює швидку мобілізацію заліза з ретикулоендотеліальних клітин та використання його для синтезу $\mathrm{Hb}$ [14]. Отже, гепсидин є основним регуляторним пептидом, що забезпечує гомеостаз заліза в організмі [15].

На цей час активно вивчається роль заліза в розвитку ЦД 1-го та 2-го типів. Відомо, що надлишок заліза в організмі людини може спричинити інсулінорезистентність і розвиток ЦД 2-го типу [16, 17]. Також описано вплив наявності залізодефіцитної анемії на рівень глікозильованого $\mathrm{Hb}$ (HbA1c) у пацієнтів із ЦД: у даної категорії хворих рівень НbA1с вищий ніж у хворих на ЦД, але без дефіциту заліза [18]. Вищі показники HbA1с спостерігаються і в осіб без ЦД, проте із анемією [18-20].

Згідно з останніми даними, 50\% хворих із хронічною хворобою нирок (ХХН) мають відносний або абсолютний залізодефіцит. Причиною цього може бути порушена чутливість тканин до еритропоетину, який, у цьому випадку, інгібує транспорт заліза з депо до еритробластів; підвищений рівень прозапальних цитокінів, зокрема інтерлейкіну-6 та секреція гепсидину [21, 22].

Однією з найчастіших причин виникнення анемії при ЦД є ХХН [23], яка характеризується тривалими (не менше 3 міс.) структурними та/або функціональними нирковими змінами за даними клінічних, лабораторних, інструментальних, морфологічних досліджень, які дають підставу для виключення гострого патологічного процесу в нирках. Поширеність ХХН серед дорослих досить висока: 14,3\% у загальній популяції, 36,1\% - у групах високого ризику (артеріальна гіпертензія, ЦД і серцево-судинні захворювання (СС3)) [24].

У США на ХХН при ЦД припадає 40\% ускладнень серед хворих на ЦД 1-го типу і 5-15\% - серед хворих на ЦД 2-го типу. В Україні при тривалості ЦД 1-го типу менш як 10 років ХХН виявляється в 5-6\% хворих, до 20 років - у 20-25\%, до 30 років - у 35-40\% і більш як 40 років - у 45\%. Максимальна частота XXН реєструється у хворих із тривалістю ЦД 1520 років. У хворих із тривалістю захворювання більш як 35-40 років за відсутності нефропатії ризик її розвитку незначний, менш як 1\% [25].

Головною причиною анемії у хворих на Цд iз XXН є зниження продукції еритропоетину в перитубулярних клітинах проксимальної частини нефрону, зниженою чутливістю кісткового мозку до його дії, залізодефіцитом, недостатністю вітаміну $\mathrm{B}_{12}$ та фолатів, важким гіперпаратиреозом, системним запаленням [26]. У нормі зниження рівня Нb супроводжується посиленням продукування ниркового еритропоетину. Але при ЦД цей зв'язок порушується, призводячи до того, що еритропоетин-синтезуючі перитубулярні фібробласти інтерстицію нирок не здатні збільшувати продукування еритропоетину у відповідь на анемію.

Критерієм встановлення зниженої чутливості рецепторів кісткового мозку до еритропоетину є потреба у високих дозах цього гормону для стабілізації рівня Нb при відсутності залізодефіциту. Крім того, еритропоетин виявляє антиапоптичні властивості на проеритробласти [27, 28]. Рецептори до еритропоетину знаходяться в багатьох тканинах поза межами кісткового мозку, зокрема в головному мозку, сітківці, кишківнику, нирках, підшлунковій залозі та легенях. Він стимулює вироблення тестостерону в чоловіків та регулює ріст судин у біометрії під час менструального циклу в жінок [29].

СС3 є найчастішою причиною смерті у хворих із кінцевою стадією ХХН. Факторами ризику виникнення СС3 у хворих із ХХН є вік, стать, ЦД, артеріальна гіпертензія, куріння й ожиріння, а специфічними при ХХН є зміни артеріального тиску, перерозподіл рідини, анемія, недостатність харчування, гіпоальбумінемія, гіпергомоцистинемія, системне запалення, оксидативний стрес, інсулінорезистентність, ендотеліальна дисфункція та зміна активності ренін-ангіотензин-альдостеронової системи [30]. ССЗ при ЦД виникають через кілька причин, зокрема, атеросклероз, який викликає багатосудинне ураження; наявність артеріальної гіпертензії. Анемія є відомим фактором, який ускладнює перебіг ССЗ: вона викликає гіпертрофію лівого шлуночка, збільшує потребу міокарда в кисні та підвищує ішемію міокарда [31, 32]. В одному з досліджень було показано, що ін'єкції еритропоетину хворим зі зниженою швидкістю клубочкової фільтрації протягом 6 міс. зменшували індекс маси міокарда [33]. Оскільки хворі на ЦД мають підвищений ризик анемії, перебіг ССЗ у них значно погіршується. 
Огляди

Крім того, активно вивчається роль гормону жирової тканини адипонектину в розвитку XXН та анемії у хворих на ЦД 2-го типу. Він секретується в білій жировій тканині та стимулює окислення жирних кислот у м'язах, тим самим підвищуючи чутливість до інсуліну, проявляє протизапальну і антиатеросклеротичну дію [34]. Низький рівень адипонектину асоціюється з розвитком ЦД та ССЗ. Вченими активно досліджується вплив адипонектину на дозрівання гемопоетичних клітин та мієломоноцитів [35-37]. Нещодавні дослідження показали, що адипонектин негативно корелює із рівнем гематопоезу та є предиктором розвитку анемії в загальній популяції. У пацієнтів із ХХН високий рівень адипонектину асоційований із низьким рівнем гемоглобіну, еритроцитів та гематокриту [38, 39].

Як було згадано вище, наявність анемії погіршує перебіг ЦД та його ускладнень. У 2010 р. 285 млн людей, котрі хворіли на ЦД, мали ретинопатію [40]. Відомими факторами ризику розвитку ретинопатії при Цд є хронічна гіперглікемія, тривалість основного захворювання та наявність артеріальної гіпертензії. Як відомо, анемія спричиняє гіпоксію, яка є головним фактором у розвитку ретинопатії та спричиняє неоваскуляризацію й оксидативний стрес [41]. У хворих з анемією в 1,8 раза збільшується ризик захворіти на діабетичну ретинопатію, причому в чоловіків цей коефіцієнт становить 2,05 [42], а важкість анемії прямо корелює зі ступенем ураження сітківки. Це може бути пов'язано 3 тим, що при анемії деформовані еритроцити закорковують судини сітківки та спричиняють гіпоксію ока $[43,44]$. Також припускається, що нестача кисню активує вазопроліферативний фактор росту 1 і викликає проліферацію судин [45]. До того ж при анемії виникає порушення метаболізму білірубіну. Як відомо, білірубін володіє антиоксидантними властивостями завдяки впливу на глікування та протеїн-кіназу C [45, 46]. Повідомляється, що білірубін може відігравати захисну роль при ЦД та кардіо-васкулярних захворюваннях [47]. Виявлено негативну кореляцію між рівнем білірубіну та діабетичною ретинопатією і її важкістю [48].

Діабетична периферична нейропатія є одним із найчастіших ускладнень Цд та зустрічається приблизно в 50\% хворих на ЦД 2-го типу [49]. Кілька досліджень довели, що хворі на ЦД 2-го типу, які мають анемію, мали тяжке порушення температурної чутливості. Крім того, у них спостерігалося порушення вібраційної чутливості, тяжчі розлади ахіллового рефлексу та знижена больова чутливість порівняно з хворими, котрі не мали анемії [50, 51]. Отже, можна припустити, що наявність анемії у хворих на ЦД 2-го типу є незалежним фактором ризику розвитку периферичної нейропатії.

Відомо, що однією з побічних дій метформіну $€$ розвиток дефіциту вітаміну $\mathrm{B}_{12}$. Він проявляється розвитком мегалобластної анемії, макроцитозом, нейропатією та нейропсихологічними розладами $[52,53]$. Крім того, дефіцит вітаміну $\mathrm{B}_{12}$ погірушує перебіг діабетичної периферичиної нейропатії [54]. Ризик виникнення цих ускладнень залежить від дози препарату та тривалості його приймання. Biтамін $\mathrm{B}_{12}$ зв'язується з кубуліновими рецепторами у дванадцятипалій кишці для абсорбції. Цей процес зазвичай відбувається завдяки кальцій-залежному транспорту. Оскільки метформін зв'язується 3 цими рецепторами та порушує транспорт кальцію, він призводить до мальабсорбції вітаміну $\mathrm{B}_{12}$ [55]. Доведено, що метформін порушує не лише всмоктування вітаміну $\mathrm{B}_{12}$, а і його перерозподіл, зокрема, збільшує його концентрацію в печінці, зменшуючи при цьому в сироватці крові [56]. У дослідженнях було показано, що в близько $40 \%$ хворих на тлі приймання метформіну понад 1 рік спостерігався рівень вітаміну $\mathrm{B}_{12}$ на нижній межі норми, а в 77\% хворих, у яких було встановлено дефіцит цього вітаміну, розвивалася периферична нейропатія. Мета-аналіз 6 рандомізованих досліджень показав, що приймання цього препарату хворими із Цд 2-го типу, синдромом полікістозних яєчників, ожирінням та ішемічною хворобою серця тісно асоційований із виникненням мегалобластичної анемії [57]. Для розв’язання цієї проблеми перспективним є щорічний скринінг на дефіцит вітаміну $\mathrm{B}_{12}$ у хворих на ЦД 2-го типу 3 подальшим терапевтичним втручанням, або ж профілактичне призначення вітаміну $\mathrm{B}_{12}$ хворим, які отримують метформін у дозі більш як 1000 мг впродовж тривалого часу без проведення скринінгу. 


\section{Висновки}

У хворих на ЦД можуть розвиватися анемії різного генезу. Анемії погіршують перебіг ЦД та пришвидшують розвиток хронічних ускладнень, зокрема ретинопатії та нейропатії. Сьогодення потребує активного вивчення сучасних маркерів розвитку анемії для ранньої діагностики залізодефіциту. Із метою виявлення анемії пацієнтам із ЦД 2-го типу необхідно проводити моніторинг рівня вітаміну $\mathrm{B}_{12}$, феритину та фолієвої кислоти в крові. Гіповітаміноз $\mathrm{B}_{12}$ прискорює розвиток периферичної полінейропатії, що істотно ускладнює перебіг ЦД 2-го типу та якість життя пацієнтів. Активна профілактика дефіциту вітаміну $\mathrm{B}_{12}$ на тлі приймання метформіну дозволить запобігати виникненню мегалобластної анемії.

\section{Список використаної літератури}

1. Корзун ЮВ, Соколова ЛК, Гирявенко ОЯ. Частота та структура анемічного синдрому у хворих на цукровий діабет. Ендокринологія. 2016;21(3):193-8 (Korzun YuV, Sokolova LK, Giryavenko OYa. The frequency and structure of anemia syndrome in patiens with diabetes mellitus. Endokrynologia. 2016;21(3):1938. Ukrainian).

2. Black RE, Victora CG, Walker SP, Bhutta ZA, Christian P, De Onis $\mathrm{M}$, et al. Maternal and child undernutrition and overweight in low-income and middle-income countries. The Lancet. 2013 Aug $3 ; 382(9890): 427-51$.

3. Neoh K, Stanworth S, Pasricha SR, Bennett MI. Estimating prevalence of functional iron deficiency anaemia in advanced cancer. Support Care Cancer. 2017 Apr;25(4):1209-14.

4. Kdigo AK. Work Group. KDIGO clinical practice guideline for acute kidney injury. Kidney Int Suppl. 2012;2(1):1-38.

5. Patel RP, Jain A. Study of anemia in primary hypothyroidism. Thyroid Res Pract. 2017 Jan;14(1):22-4.

6. Deray G, Heurtier A, Grimaldi A, Launay Vacher V, Isnard Bagnis C. Anemia and diabetes. Am J Nephrol. 2004 Sep-Oct;24(5):522-6.

7. Thomas MC, MacIsaac RJ, Tsalamandris C, Power D, Jerums G. Unrecognized anemia in patients with diabetes: a crosssectional survey. Diabetes Care. 2003 Apr;26(4):1164-9.

8. Camargo JL, Gross JL. Conditions associated with very low values of glycohaemoglobin measured by an HPLC method. J Clin Pathol. 2004 Apr;57(4):346-9.

9. Eisenstein RS, Blemings KP. Iron regulatory proteins, iron responsive elements and iron homeostasis. J Nutr 1998 Dec;128(12):2295-8.

10. Видиборець СВ, Андріяка АО. Физиологическая роль гепсидина как центрального регулятора метаболизма железа. Семейная медицина. 2017;(1):154-7 (Vydyborets SV, Andriyaka AA Hepsidin: physiological role how central regulator of iron metabolism. Family medicine. 2017;(1):154-7)

11. Hardang IM, Lilleholt K, Hagve TA. Anemia of chronic disease Tidsskr Nor Laegeforen. 2017 Sep 18;137(17).

12. Papanikolaou G, Tzilianos M, Christakis JI, Bogdanos D Tsimirika K, MacFarlane J, et al. Hepcidin in iron overload disorders. Blood. 2005 May 15;105(10):4103-5.

13. Swaminathan S, Fonseca VA, Alam MG, Shah SV. The role of iron in diabetes and its complications. Diabetes Care. 2007 Jul;30(7):1926-33.

14. Rajpathak SN, Crandall JP, Wylie-Rosett J, Kabat GC, Rohan TE, $\mathrm{Hu}$ FB. The role of iron in type 2 diabetes in humans. Biochim Biophys Acta. 2009 Jul;1790(7):671-81.
15. Guo W, Zhou Q, Jia Y, Xu J. Increased levels of glycated hemoglobin A1c and iron deficiency anemia: A review. Med Sci Monit. 2019 Nov 7;25:8371-8

16. El-Agouza I, Abu Shahla A, Sirdah M. The effect of iron deficiency anaemia on the levels of haemoglobin subtypes: possible consequences for clinical diagnosis. Clin Lab Haematol. 2002 Oct;24(5):285-9.

17. Coban E, Ozdogan M, Timuragaoglu A. Effect of iron deficiency anemia on the levels of hemoglobin A1c in nondiabetic patients. Acta Haematol. 2004;112(3):126-8.

18. Mezzano S, Droguett A, Burgos ME, Ardiles LG, Flores CA Aros CA, et al. Renin-angiotensin system activation and interstitial inflammation in human diabetic nephropathy. Kidney Int Suppl. 2003 Oct; (86): S64-70.

19. Hernik A, Szczepanek-Parulska E, Filipowicz D, Czarnywojtek A, Wrotkowska E, Kramer L, et al. Hepcidin and iron homeostasis in patients with subacute thyroiditis and healthy subjects. Mediators Inflamm. 2019 Feb 27;2019:5764061

20. Duong U, Mehrotra R, Molnar MZ, Noori N, Kovesdy CP, Nissenson AR, et al. Glycemic control and survival in peritoneal dialysis patients with diabetes mellitus. Clin J Am Soc Nephrol. 2011 May;6(5):1041-8.

21. Ene-Iordache B, Perico N, Bikbov B, Carminati S, Remuzzi A, Perna A, et al. Chronic kidney disease and cardiovascular risk in six regions of the world (ISN-KDDC): a cross-sectional study. Lancet Glob Health. 2016 May;4(5): e307-19.

22. Thomas MC. Anemia in diabetes: marker or mediator of microvascular disease? Nat Clin Pract Nephrol. 2007 Jan;3(1):20-30.

23. Erslev AJ, Besarab A. Erythropoietin in the pathogenesis and treatment of the anemia of chronic renal failure. Kidney Int. 1997 Mar;51(3):622-30.

24. Choi D, Schroer SA, Lu SY, Wang L, Wu X, Liu Y, et al. Erythropoietin protects against diabetes through direct effects on pancreatic $\beta$ cells. J Exp Med. 2010 Dec 20;207(13):2831-42.

25. Rao AM, Bitla AR, Reddy EP, Sivakumar V, Rao PS. Lipid abnormalities, lipoprotein (a) and apoprotein pattern in nondialyzed patients with chronic kidney disease. Indian J Clin Biochem. 2010 Jan;25(1):47-50.

26. Sathyan S, George S, Vijayan P. Prevalence of anemia and cardiovascular diseases in chronic kidney disease patients: A single tertiary care centre study. Int J Adv Med. 2017 Feb;4(1):247-51.

27. Babua C, Kalyesubula R, Okello E, Kakande B, Sebatta E, Mungoma M, et al. Cardiovascular risk factors among patients with chronic kidney disease attending a tertiary hospital in Uganda. Cardiovasc J Afr. 2015 Jul-Aug;26(4):177-80.

28. Hayashi T, Suzuki A, Shoji T, Togawa M, Okada N, Tsubakihara Y, et al. Cardiovascular effect of normalizing the hematocrit level during erythropoietin therapy in predialysis patients with chronic renal failure. Am J Kidney Dis. 2000 Feb;35(2):250-6.

29. Урбанович АМ. Гормони жирової тканини та їх клінічне значення. Ендокринологія. 2013 Mar 20;18(1):69-72 (Urbanovich AM. Hormones of adipose tissue and their clinical significance. Endokrynologia. 2013 Mar 20;18(1):69-72. Ukrainian).

30. Yokota T, Oritani K, Takahashi I, Ishikawa J, Matsuyama A, Ouchi N, et al. Adiponectin, a new member of the family of soluble defense collagens, negatively regulates the growth of myelomonocytic progenitors and the functions of macrophages. Blood, 2000 Sep 1;96(5):1723-32.

31. Wilson A, Fu H, Schiffrin M, Winkler C, Koufany M, Jouzeau JY, et al. Lack of adipocytes alters hematopoiesis in lipodystrophic mice. Front Immunol. 2018 Nov 13;9:2573.

32. Crawford LJ, Peake R, Price S, Morris TC, Irvine AE. Adiponectin is produced by lymphocytes and is a negative regulator of granulopoiesis. J Leukoc Biol. 2010 Oct;88(4):807-11.

33. Aso Y, Suganuma R, Wakabayashi S, Hara K, Nakano T, Suetsugu M, et al. Anemia is associated with an elevated serum level of high-molecular-weight adiponectin in patients with type 2 diabetes independently of renal dysfunction. Transl Res. 2009 Oct;154(4):175-82

34. Tsuboi A, Watanabe M, Kazumi T, Fukuo K. Anemia and reduced renal function are independent predictors of elevated serum adiponectin in elderly women. J Atheroscler Thromb. 2013;20(6):568-74.

35. Jin G, Xiao W, Ding X, Xu X, An L, Congdon N, et al. Prevalence of and risk factors for diabetic retinopathy in a rural Chinese 
Огляди

population: the Yangxi eye study. Invest Ophthalmol Vis Sci. 2018 Oct 1;59(12):5067-73.

36. Ito H, Takeuchi Y, Ishida H, Otawa A, Shibayama A, Antoku S, et al. Mild anemia is frequent and associated with micro-and macroangiopathies in patients with type 2 diabetes mellitus. J Diabetes iInvestig. 2010 Dec 3;1(6):273-8.

37. Curtis TM, Gardiner TA, Stitt AW. Microvascular lesions of diabetic retinopathy: clues towards understanding pathogenesis? Eye (Lond). 2009 Jul;23(7):1496-508.

38. Ranil PK, Raman R, Rachepalli SR, Pal SS, Kulothungan V, Lakshmipathy P, et al. Anemia and diabetic retinopathy in type 2 diabetes mellitus. J Assoc Physicians India. 2010 Feb;58:91-4.

39. Browning DJ, Stewart MW, Lee C. Diabetic macular edema: Evidence-based management. Indian J Ophthalmol. 2018 Dec;66(12):1736-50.

40. Gong Q, Li F, Su G. Upregulated VEGF and Robo4 correlate with the reduction of miR-15a in the development of diabetic retinopathy. Endocrine. $2019 \mathrm{Jul} ; 65(1): 35-45$.

41. Neuzil J, Stocker R. Free and albumin-bound bilirubin are efficient co-antioxidants for alpha-tocopherol, inhibiting plasma and low density lipoprotein lipid peroxidation. J Biol Chem. 1994 Jun 17;269(24):16712-9.

42. Kalousova M, Novotny L, Zima T, Braun M, Vitek L. Decreased levels of advanced glycation end-products in patients with Gilbert syndrome. Cell Mol Biol (Noisy-le-grand). 2005 Sep 30;51(4):387-92.

43. Sekioka R, Tanaka M, Nishimura T, Itoh H. Serum total bilirubin concentration is negatively associated with increasing severity of retinopathy in patients with type 2 diabetes mellitus. J Diabetes Complications. 2015 Mar;29(2):218-21.

44. Pop-Busui R, Boulton AJ, Feldman EL, Bril V, Freeman R, Malik RA, et al. Diabetic neuropathy: a position statement by the American Diabetes Association. Diabetes Care. 2017 Jan;40(1):136-54.

45. Bosman DR, Winkler AS, Marsden JT, Macdougall IC, Watkins PJ. Anemia with erythropoietin deficiency occurs early in diabetic nephropathy. Diabetes Care. 2001 Mar;24(3):495-9.

46. Wu F, Jing Y, Tang X, Li D, Gong L, Zhao H, et al. Anemia: an independent risk factor of diabetic peripheral neuropathy in type 2 diabetic patients. Acta Diabetol. 2017 Oct;54(10):925-31.

47. Ahmed MA. Metformin and vitamin $B_{12}$ deficiency: where do we stand? J Pharm Pharm Sci. 2016 Jul-Sep;19(3):382-98.

48. Abdelgawad FE. Serum vitamin $B_{12}$ and homocysteine levels in type 2 diabetic patients with and without metformin therapy. J Biomed Sci Engineer. 2019 Dec;12(12):557-570.

49. Owhin SO, Adaja TM, Fasipe OJ, Akhideno PE, Kalejaiye OO, Kehinde MO. Prevalence of vitamin $B_{12}$ deficiency among metformin-treated type 2 diabetic patients in a tertiary institution, SouthSouth Nigeria. SAGE Open Med. 2019 May 23;7:2050312119853433.

50. Akinlade KS, Agbebaku SO, Rahamon SK, Balogun WO. Vitamin $\mathrm{B}_{12}$ levels in patients with type 2 diabetes mellitus on metformin. Ann Ib Postgrad Med. 2015 Dec;13(2):79-83.

51. Rice L. Food Cobalamin Malabsorption: A Usual Cause of Vitamin $\mathrm{B}_{12}$ Deficiency-Reply. Arch Intern Med. $2000 \mathrm{Jul} ; 160(13): 2061-7$.

52. Greibe E, Miller JW, Foutouhi SH, Green R, Nexo E. Metformin increases liver accumulation of vitamin $\mathrm{B}_{12}$-an experimental study in rats. Biochimie. 2013 May;95(5):1062-5.

53. Yang W, Cai X, Wu H, Ji L. Associations between metformin use and vitamin $B_{12}$ levels, anemia, and neuropathy in patients with diabetes: a meta-analysis. J Diabetes. 2019 Sep;11(9):729-43.

54. Wong CW, Leung CS, Leung CP, Cheng JN. Association of metformin use with vitamin $\mathrm{B}_{12}$ deficiency in the institutionalized elderly. Arch Gerontol Geriatr. 2018 Nov-Dec;79:57-62.

55. Gupta K, Jain A, Rohatgi A. An observational study of vitamin $B_{12}$ levels and peripheral neuropathy profile in patients of diabetes mellitus on metformin therapy. Diabetes Metab Syndr. 2018 Jan-Mar;12(1):51-8.

56. Chapman LE, Darling AL, Brown JE. Association between metformin and vitamin $\mathrm{B}_{12}$ deficiency in patients with type 2 diabetes: A systematic review and meta-analysis. Diabetes Metab. 2016 Nov;42(5):316-27.

57. Паньків ВI. Взаємозв'язок між прийомом метформіну й дефіцитом вітаміну $\mathrm{B}_{12}$ у хворих на цукровий діабет 2-го типу. Міжнародний ендокринологічний журнал. 2019;15(1):38-43 (Pankiv VI. Association between metformin use and vitamin $\mathrm{B}_{12}$ deficiency in patients with type 2 diabetes. International Journal of Endocrinology (Ukraine). 2019;15(1):38-43. Ukrainian).

\section{Особенности течения анемического синдрома у больных сахарным диабетом}

\section{А.М. Урбанович, Ю.В. Дунец}

Львовский национальный медицинский университет имени Данила Галицкого

Резюме. В этом обзоре освещены особенности течения анемий различной этиологии у больных сахарным диабетом. СД 一 одно из самых распространенных хронических заболеваний, которое постепенно приобретает черты неинфекционной эпидемии и является одной из самых острых медико-социальных проблем современности, охватывающей большинство экономически развитых государств. Поскольку сахарный диабет поражает все органы и системы организма, анемический синдром может иметь мультифакторный генез. Снижение уровня гемоглобина ухудшает контроль углеводного обмена, способствует быстрому развитию диабетической ретинопатии и нейропатии. Пациенты с сахарным диабетом пребывают в зоне риска по развитию железодефицитной анемии и анемии, связанной с дефицитом эритропоэтина из-за развития хронической болезни почек. Железодефицитная анемия является самой распространенной среди всех пациентов, в том числе и у больных СД. Гуморальным регулятором уровня железа в организме является гепсидин, который представляет собой аминокислотный пептид, богатый на цистеин, с дисульфидными мостиками, и синтезируется в печени. Известно, что при гипоксии уменьшается експрессия гена гепсидина и увеличивается усвоение железа как с макрофагов, так и из кишечника, соответственно гепсидин является основным регуляторным пептидом, который обеспечивает гомеостаз железа в организме. С развитием диабетической хронической болезни почек, вероятность развития анемии резко возрастает, поскольку возникает дефицит эритропоэтина. Также постоянный прием метформина, который является препаратом первой линии для лечения СД 2-го типа, повышает вероятность возникновения $\mathrm{B}_{12}$-дефицитной анемии. Активная профилактика, ранняя диагностика и лечение анемии у больных сахарным диабетом позволит замедлить развитие хронических осложнений и улучшить качество жизни пациентов.

Ключевые слова: анемия, сахарный диабет, хроническая болезнь почек, гепсидин, метформин.

\section{Peculiarities of the course of anemic syndrome in patients with diabetes mellitus}

\author{
A.M. Urbanovych, Yu.V. Dunets \\ Danylo Halytsky Lviv National Medical University
}

Abstract: This review highlights the features of anemia of different etiology in patients with diabetes. Diabetes mellitus is one of the most common chronic diseases, which is gradually becoming a non-communicable epidemic and, therefore, acute medical and social current problems in high-income countries. Because diabetes affects all organs and systems of the body, the anemic syndrome can have various etiology. 
Decreased level of hemoglobin impairs carbohydrate metabolism, accelerates the development of diabetic retinopathy and neuropathy. Patients with diabetes are at risk of iron deficiency anemia and anemia associated with erythropoietin deficiency due to the development of chronic kidney disease. Iron deficiency anemia is the most common type of anemia among all patients, including those with diabetes. The humoral regulation of iron levels in the human body is carried out by hepcidin, which is an amino acid peptide enriched by cysteine, with disulfide bridges; it is synthesized in the liver. It is known that hypoxia reduces the expression of the hepcidin gene and increases the absorption of iron in both macrophages and intestines; so, hepcidin is the main regulatory peptide that maintains iron homeostasis. While the preogression of chronic kidney disease in diabetic people, the likelihood of anemia developing sharply increases, as there is a deficiency of erythropoietin. Also, regular use of metformin, which is a first-line drug for the treatment of type 2 diabetes, increases the risk of $\mathrm{B}_{12}$-deficiency anemia. Active prevention and treatment of anemia in patients with diabetes will slow the development of chronic complications and improve the quality of life of patients.

Keywords: anemia, diabetes mellitus, chronic kidney disease, hepcidin, metformin.

Для цитування: Урбанович АМ, Дунець ЮВ. Особливості перебігу анемічного синдрому у хворих на цукровий діабет. Ендокринологія. 2021;26(1):75-81. DOI:.10.31793/1680-1466.2020.26-1.75.

Адреса для листування: Урбанович Аліна Мечиславівна; alinaur@dr.com; Львівський національний медичний університет імені Данила Галицького; вул. Пекарська, 69, Львів 79010, Україна.

Відомості про авторів: Урбанович Аліна Мечиславівна, д-р мед. наук, проф., завідувачка кафедри ендокринології. ORCID: 0000-0003-3676-7345; Дунець Юлія Вікторівна, аспірант, асистент кафедри ендокринології; ORCID: 0000-0002-9275-0540.

Особистий внесок: А.М. Урбанович - аналіз проблеми, розробка концепції статті, пошук та аналіз даних, Ю.В. Дунець - пошук та аналіз даних, підготовка статті.

Фінансування: стаття підготовлена в рамках виконання планової НДР кафедри ендокринології ЛНМУ імені Данила Галицького «Особливості патогенезу, діагностики та лікування захворювань серцево-судинної, травної, ендокринної та дихальної систем в клініці та експерименті» (№ держреєстрації 0120U002142).

Декларація з етики: автори задекларували відсутність конфлікту інтересів та фінансових зобов'язань.

Стаття: надійшла до редакції 28.02.2021 р.; перероблена 03.03.2021 р.; прийнята до друку 04.03.2021р.; надрукована 30.03.2021 p.
Для цитирования: Урбанович АМ, Дунец ЮВ. Особенности течения анемического синдрома у больных сахарным диабетом. Эндокринология. 2021;26(1):75-81. DOI: 10.31793/16801466.2020.26-1.75.

Адрес для переписки: Урбанович Алина Мечиславовна; alinaur@dr.com; Львовский национальный медицинский университет имени Данила Галицкого, ул. Пекарская, 69, Львов 70010, Украина.

Сведения об авторах: Урбанович Алина Мечиславовна, д-р мед. наук, профессор кафедры эндокринологии. ORCID: 00000003-3676-7345; Дунец Юлия Викторовна, аспирант, асистент кафедры эндокринологии; ORCID: 0000-0002-9275-0540.

Личный вклад: А.М Урбанович - анализ проблемы, разработка концепции статьи, поиск и анализ данных, Ю.В Дунец — поиск и анализ данных, подготовка статьи.

Финансирование: статья подготовлена в рамках выполнения плановой НИР «Особенности патогенеза, диагностики и лечения заболеваний сердечно-сосудистой, пищеварительной, эндокринной и дыхательной систем в клинике и эксперименте» (№ госрегистрации 0120U002142).

Декларация по этике: авторы задекларировали отсутствие конфликта интересов и финансовых обязательств.

Статья: поступила в редакцию 28.02.2021 г;; переработана 03.03.2021 г.; принята в печать 04.03.2021 г.; напечатана 30.03.2021 г.

For citation: Urbanovych AM, Dunets YV. Peculiarities of the course of anemic syndrome in patients with diabetes millitus. Endokrynologia. 2021;26(1):75-81. DOI: 10.31793/16801466.2020.26-1.75.

Correspondence address: Urbanovych AM; alinaur@dr.com, Danylo Halytsky Lviv National Medical University, Lviv, Ukraine, 69 Pekarska street, city of Lviv, 79010.

Information about the authors: Alina Urbanovych, Dr. Sci. (Medicine), Prof., Head of the Department of Endocrinology, ORCID: 0000-0003-3676-7345, Yulia Dunets, Asistent at the Department of Endocrinology, ORCID: 0000-0002-9275-0540.

Authors' contributions: A.M. Urbanovych - analysis of problem, development article concept, data search and analysis; Y.V. Dunets - searching material, preparation of the article.

Funding: the article was prepared as part of the planned research work «Features of the pathogenesis, diagnosis and treatment of diseases of the cardiovascular, digestive, endocrine and respiratory systems in the clinic end experiment».

Declaration of ethics: the authors have declared no conflict of interest and financial obligations.

Article: received 28 February 2021; revised 03 March 2021; accepted 04 March 2021; published 30 March 2021. 